\title{
Article
}

\section{Welding of mobile elevating work platforms}

\author{
Abilio Silva ${ }^{1}$, Bożena Szczucka-Lasota ${ }^{2}$, Tomasz Węgrzyn ${ }^{2, *}$, Adam Jurek ${ }^{3}$ \\ ${ }^{1}$ University da Beira Interior, Covilha, Portugal \\ prof. Abilio Silva abilio@ubi.pt; \\ 2 Silesian University of Technology, Poland \\ prof. Bożena Szczucka-Lasota, bozena.szczucka-lasota@polsl.pl; \\ ${ }^{3}$ Novar Sp. z o. o. Gliwice, Poland \\ * Correspondence: prof. Tomasz Węgrzyn, Tomasz.Wegrzyn@polsl.pl
}

Received: 02.05.2019; Accepted: 14.06.2019

\begin{abstract}
The demand for new welding technologies in civil engineering and transport is increasing. An example of this is the tendency to increase the operating range of a mobile platform mounted on motor vehicles while maintaining the weight of the vehicle. The most commonly used material in the production of mobile platforms are AHSS steels due to their high tensile strength at the level of 1400 $\mathrm{MPa}$. However, the joints created with their use are characterized by much lower strength than the native material. In this article, the most appropriate parameters for welding elements of a mobile platform from difficult-to-use steel AHSS were selected.
\end{abstract}

Key words: civil engineering; transport; mobile platforms; AHSS; martensitic steel

\section{Introduction}

In civil engineering and transport, the modernization of construction and transport equipment is observed. A representative example is the modernization of mobile platforms allowing for their increasing operational range, while maintaining the lowest possible mass of the vehicle [1].

The updated legislation on exhaust emissions in motor vehicles requires the introduction of additional components such as: diesel particulate filters, exhaust gas catalysts, components of exhaust systems, which significantly increase the total weight of vehicles. In trucks, the weight gain can be up to $200 \mathrm{~kg}$ [1]. In recent years, there has been a significant increase in the use of high strength steels in various areas of welded structures [2,3].

In order to increase the usable properties of the platform structures, it is also aimed at increasing their tensile strength. This article aims to select the welding parameters for thin-walled construction of mobile platform elements made of Advanced High-Strength Steel (AHSS).

\section{Materials and research methods}

Advanced high-strength steels find increasingly widespread use in civil engineering and transport due to their high tensile strength, up to $1400 \mathrm{MPa}$, high yield strength of around $1200 \mathrm{MPa}$ and an acceptable relative elongation of $10 \%$ [4:7]. During welding of AHSS, a decrease in mechanical properties in the heat-affected zone (HAZ) as well as an increased susceptibility to time-delay cracking can be observed. It is therefore recommended to limit the heat input during welding to the level of $5 \mathrm{~kJ} / \mathrm{cm} \mathrm{[8]}$ and to use welding energy sources that enable precise control of the amount of energy introduced into the welded joint $[9,10]$. In order to improve the weldability of steel, it is proposed to introduce cooling that promotes martensitic transformation $[8,11]$.

AHSS are mainly used for thin-walled constructions, because their high strength allows to reduce the total weight of the structure. The main welding problem of this group of steel, however, is much lower strength of the joint formed than the native material and inferior plastic properties, which measure is the relative elongation $[12 \div 20]$. Table I presents the most important two steel grades from the AHSS group, which are used for the construction of mobile platforms and their mechanical properties $[17 \div 20]$.

Steels from the AHSS group are considered to be difficult to weld, because the heat affected zone is susceptible to welding cracks even with preheating to max. $120^{\circ} \mathrm{C}$. This is due to their structure in which martensite prevails. Table II presents the chemical composition of the tested AHSS steels used for the construction of mobile platforms. 
Table I. Selected types of AHSS steel dedicated to building of mobile elevating work platforms - mechanical properties [13]

\begin{tabular}{cccccccc}
\hline Steel grade & $\begin{array}{c}\text { Yield strength } \\
R_{\mathbf{e}}\left(\mathbf{N} / \mathbf{m m}^{2}\right)\end{array}$ & $\begin{array}{c}\text { Yield strength } \\
\text { after heat curing }\end{array}$ & $\begin{array}{c}\text { Tensile strength } \\
\mathbf{R}_{\mathbf{m}}\left(\mathbf{N} / \mathbf{m m}^{2}\right)\end{array}$ & $\begin{array}{c}\text { Elongation } \\
\mathbf{R}_{80} \%\end{array}$ & $\begin{array}{c}\text { Minimum } \\
\text { bending } \\
\text { radius for the } \\
\mathbf{a n g l e ~} \mathbf{9 0}^{\circ}\end{array}$ \\
\hline DOCOL 1200M & 950 & - & $\min$ & $\min$ & $\max$ & $\min$ & $3,0 \times$ thickness \\
DOCOL 1400M & 1150 & - & 1150 & 1200 & 1400 & 3 & $3,0 \times$ thickness \\
\hline
\end{tabular}

Table II. Selected types of AHSS steel dedicated to building of mobile elevating work platforms - chemical properties [13]

\begin{tabular}{ccccccccc}
\hline Steel grade & $\mathbf{C} \%$ & $\mathbf{S i} \%$ & $\mathbf{M n} \%$ & $\mathbf{P} \%$ & $\mathbf{S} \%$ & $\mathbf{A l} \%$ & $\mathbf{N b} \%$ & $\mathbf{T i} \%$ \\
\hline DOCOL 1200M & 0.11 & 0.20 & 1.70 & 0.010 & 0.002 & 0.040 & 0.015 & 0.025 \\
DOCOL 1400M & 0.17 & 0.20 & 1.40 & 0.010 & 0.002 & 0.040 & 0.015 & 0.025 \\
\hline
\end{tabular}

The chemical composition of both steels is similar. Noteworthy is the higher carbon content in DOCOL $1400 \mathrm{M}$ steel compared to DOCOL $1200 \mathrm{M}$ steel, which translates into increased tensile strength of the material.

The work analyzed the weldability of both mentioned steel grades. The tests were carried out on sheets with a thickness of $2 \mathrm{~mm}$, because for the construction of mobile lifts components, mainly structures with a thickness of less than $3 \mathrm{~mm}$ are used [1].

Metal Active Gas (MAG) joints were made using $\mathrm{CO}_{2}$ as a shielding gas and $98 \% \mathrm{Ar}+2 \% \mathrm{O}_{2}$ and $82 \% \mathrm{Ar}+18 \% \mathrm{CO}_{2}$ mixture. Electrode wire UNION X90 (EN ISO 16834-A G 896 M21 Mn4Ni2CrMo) with the chemical composition contained in Table III was chosen.

Table III. Consumable material, elctrode wire UNION X90 - chemical composition [14]

\begin{tabular}{cccccccc}
\hline $\mathbf{C} \%$ & $\mathbf{S i} \%$ & $\mathbf{M n} \%$ & $\mathbf{P} \%$ & $\mathbf{C r} \%$ & $\mathbf{M o} \%$ & $\mathbf{N i} \%$ & $\mathbf{T i} \%$ \\
\hline 0.1 & 0.8 & 1.8 & 0.010 & 0.35 & 0.6 & 2.3 & 0.005 \\
\hline
\end{tabular}

The chemical composition of wire and steel is similar. Noteworthy is the higher silicon content in the wire in relation to the chemical composition of the steel tested. It affects the increase of strength. In turn, the increased content of nickel and molybdenum improves the plastic properties of the weld.

Welding parameters for both steels using the tested mixtures were the same: the diameter of the electrode wire was $1.0 \mathrm{~mm}$, arc voltage $19 \mathrm{~V}$, welding current $115 \mathrm{~A}$, welding speed $300 \mathrm{~mm} / \mathrm{min}$, direct current source $(+)$ on the electrode.

The method of preparation of moving platform elements for welding and the joint made is shown in figures 1 and 2. Welding was carried out using a ceramic washer.

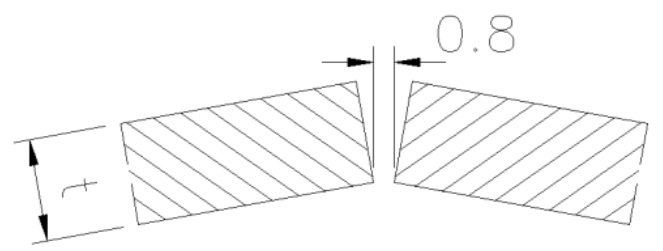

Fig. 1. Method of preparing the samples for MAG welding

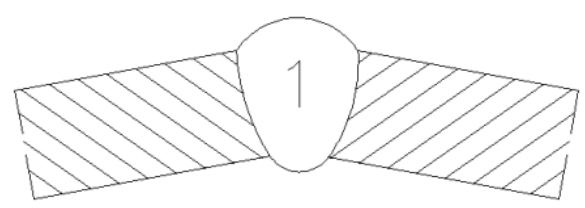

Fig. 2. The method of MAG welded joint

After welding, non-destructive examinations (NDT) were carried out:

- Visual testing (VT) of welded joints made with an eye armed with a $3 \times$ magnifying glass - the tests were performed according to the requirements of PN-EN ISO 17637 assessment criteria according to EN ISO 5817; 
- Magnetic particle testing (MT) - tests were carried out according to PN-EN ISO 17638, evaluation of tests was carried out according to EN ISO 5817, using magnetic flaw detection device of REM-230 type.

\section{Results and discussion}

The results of non-destructive tests are presented in Table III. Observations of welded joints of a mobile platform, made in the shielding gas mixture, allow to state that:

a) the use of a shielding gas mixture in the form of $\mathrm{CO}_{2}$ and $98 \% \mathrm{Ar}+2 \% \mathrm{O}_{2}$ leads to cracks in the heat affected zone;

b) in the case of $\mathrm{CO}_{2}$ shielding gas, cracks in the weld itself are additionally observed..

Table III. NDT evaluation of mobile elevating work platforms welded joints

\begin{tabular}{cccc}
\hline \multicolumn{1}{c}{ Stal } & \multicolumn{2}{c}{$\begin{array}{c}\text { Shielding gas } \\
\mathbf{8 2} \% \mathbf{~ A r}+\mathbf{1 8} \% \mathbf{C O}_{2}\end{array}$} & $\mathbf{9 8 \% ~} \mathbf{A r}+\mathbf{2} \% \mathbf{~ O}_{\mathbf{2}}$ \\
\hline DOCOL 1200M & Cracks in the joints and HAZ & No cracks & Cracks in the HAZ \\
DOCOL 1400M & Cracks in the joints and HAZ & No cracks & Cracks in the HAZ \\
\hline
\end{tabular}

Based on the data in Table III, it can be concluded that the appropriate shielding gas for welding DOCOL $1200 \mathrm{M}$ and DOCOL $1400 \mathrm{M}$ steels is a mixture of $82 \% \mathrm{Ar}+18 \% \mathrm{CO}_{2}$. This is confirmed by the photographic documentation. An example of the surface condition of welds obtained in the welding process

in the $98 \% \mathrm{Ar}+2 \% \mathrm{O}_{2}$ shield is presented in figures 3 and 4 . Figure 3 shows the view of a joint made of DOCOL 1200M steel after MAG welding from the root side. In turn, figure 4 shows the condition of the joint from the side of the face made of DOCOL 1400M steel.

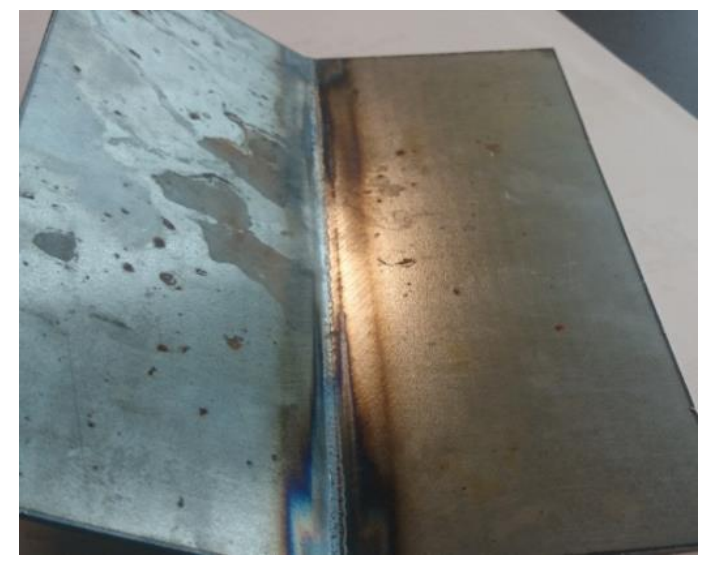

Fig. 3. View of the DOCOL $1200 \mathrm{M}$ steel joint after MAG welding using the shielding gas mixture $82 \% \mathrm{Ar}+18 \% \mathrm{CO}_{2}$ from the root side

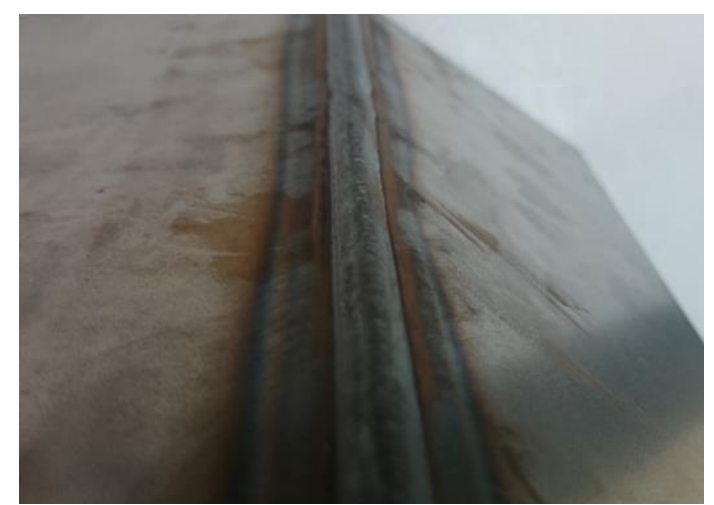

Fig. 4. View of the DOCOL $1400 \mathrm{M}$ steel joint after MAG welding using the shielding gas mixture $82 \% \mathrm{Ar}+18 \% \mathrm{CO}_{2}$ from the face side

Both joints are characterized by proper construction, visual examination did not reveal imperfections and surface defects from the side of the root and face. Analysis of the obtained results of non-destructive testing clearly indicates that MAG welding in the $82 \% \mathrm{Ar}+18 \% \mathrm{CO}_{2}$ shielding gas mixture gave better 
results than MAG welding in the cover of the other gases tested, therefore the samples made with the MAG method in the $82 \% \mathrm{Ar}+18 \% \mathrm{CO}_{2}$ shielding gas mixture were selected for strength tests.

After obtaining positive results of non-destructive tests, the tensile strength tests under static conditions of the welded elements of the platform were carried out. The strength of the joints made was tested using the INSTRON 3369 testing machine. The following analyzes were carried out:

- strength of DOCOL $1200 \mathrm{M}$ steel,

- strength of DOCOL 1400M steel.

Each test was repeated 3 times (samples 1,2,3). The results of strength tests are presented in figures 5 and 6 and in Tables V and VI.

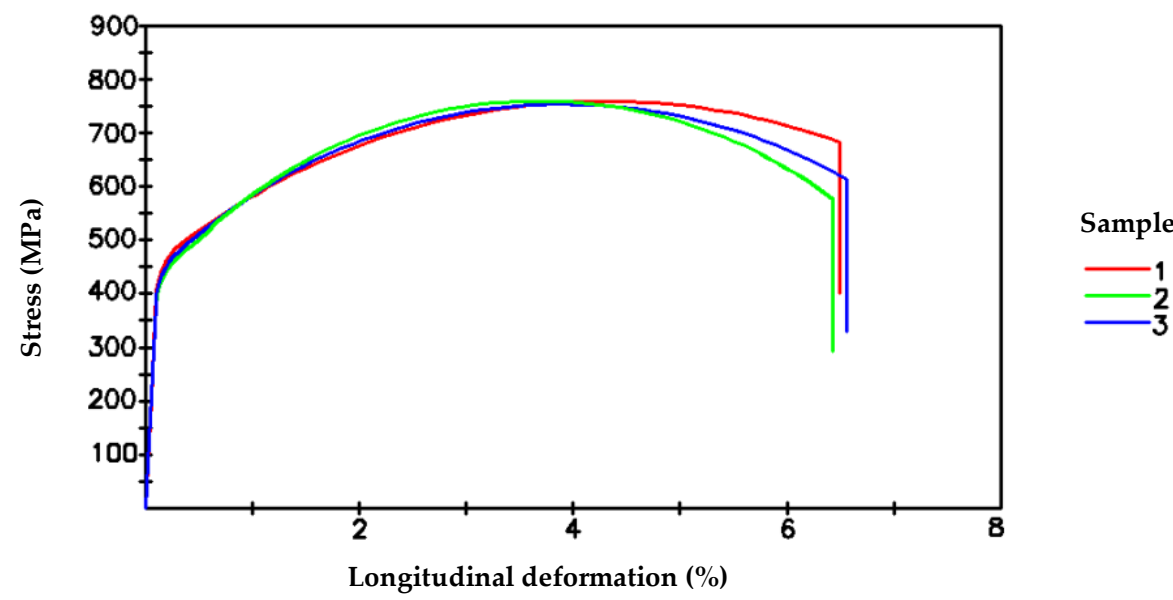

Fig. 5. The results of the DOCOL $1200 \mathrm{M}$ steel joint strength test

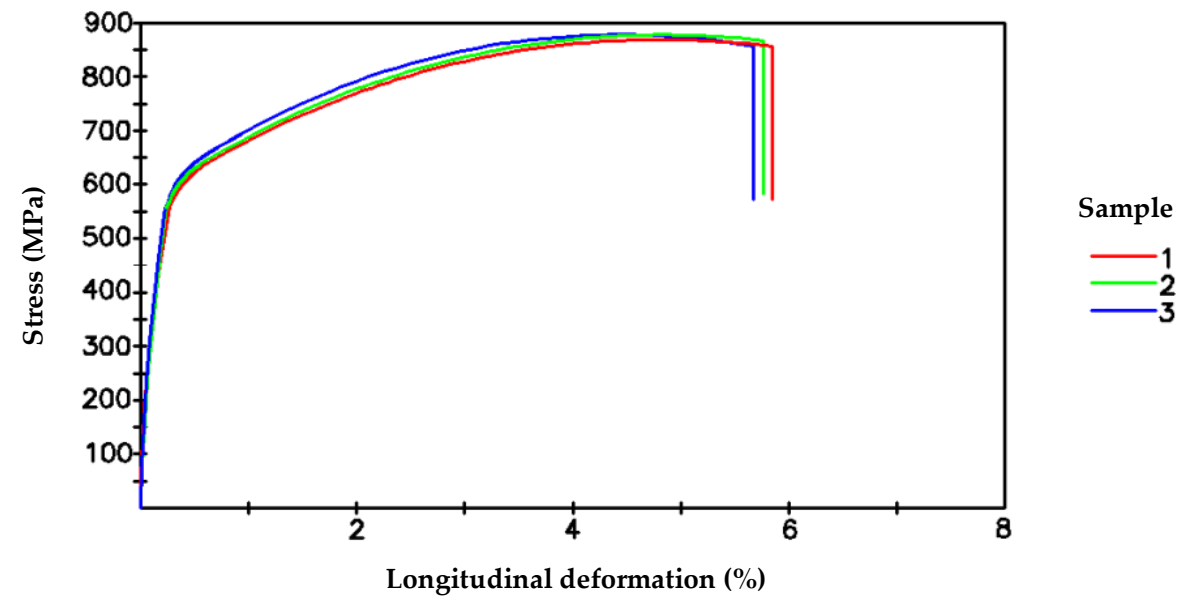

Fig. 6. The results of the DOCOL $1400 \mathrm{M}$ steel joint strength test

Table V. Results of strength tests of DOCOL 1200M welded joints, breaking in HAZ

\begin{tabular}{cccc}
\hline Sample & $\mathbf{R}_{\mathbf{e}}[\mathrm{MPa}]$ & $\mathbf{R}_{\mathbf{m}}[\mathrm{MPa}]$ & $\mathbf{A}_{5}$ \\
\hline 1 & 447 & 754 & 6,6 \\
2 & 441 & 729 & 6,5 \\
3 & 452 & 758 & 6,4 \\
Average & 447 & 747 & 6,5 \\
\hline
\end{tabular}

Table VI. Results of strength tests of DOCOL 1400M welded joints, breaking in HAZ

\begin{tabular}{cccc}
\hline Sample & $\mathbf{R}_{\mathbf{e}}[\mathrm{MPa}]$ & $\mathbf{R}_{\mathrm{m}}[\mathrm{MPa}]$ & $\mathbf{A}_{5}$ \\
\hline 1 & 551 & 897 & 5,6 \\
2 & 542 & 895 & 5,8 \\
3 & 559 & 883 & 5,7 \\
Average & 548 & 892 & 5,7 \\
\hline
\end{tabular}


Tensile strength of DOCOL 1200M steel joints was over $700 \mathrm{MPa}$ and for DOCOL 1400M steel it was above $850 \mathrm{MPa}$. Breaking of the samples occurred in the heat affected zone.

The analysis of the microstructure of DOCOL $1200 \mathrm{M}$ steel welded using MAG in $82 \% \mathrm{Ar}+18 \% \mathrm{CO}_{2}$ and $98 \% \mathrm{Ar}+2 \% \mathrm{O}_{2}$ mixture was performed. The microstructure of the cross-section of the weld with the dominant area with a martensitic structure is shown in figures 7 and 8 .

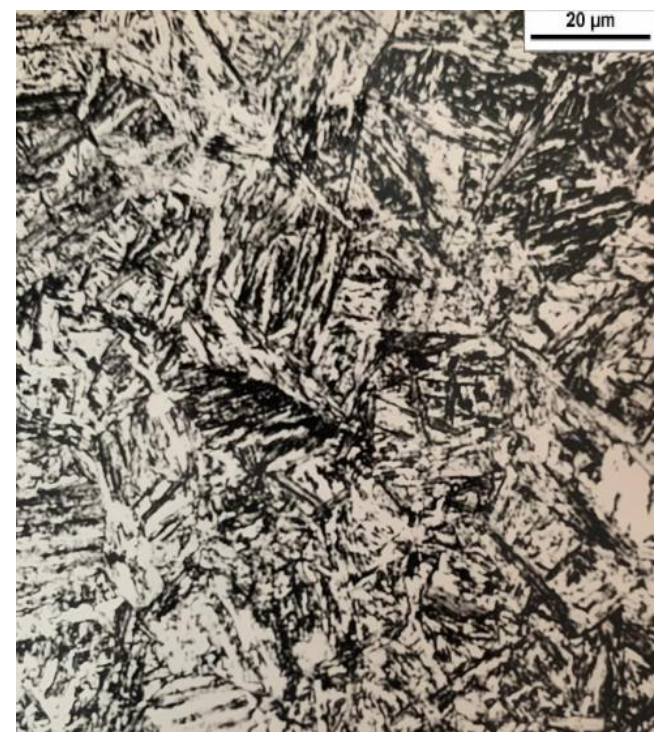

Fig. 7. Welding microstructure in DOCOL $1200 \mathrm{M}$ welded MAG steel with $82 \% \mathrm{Ar}+18 \% \mathrm{CO}_{2}$

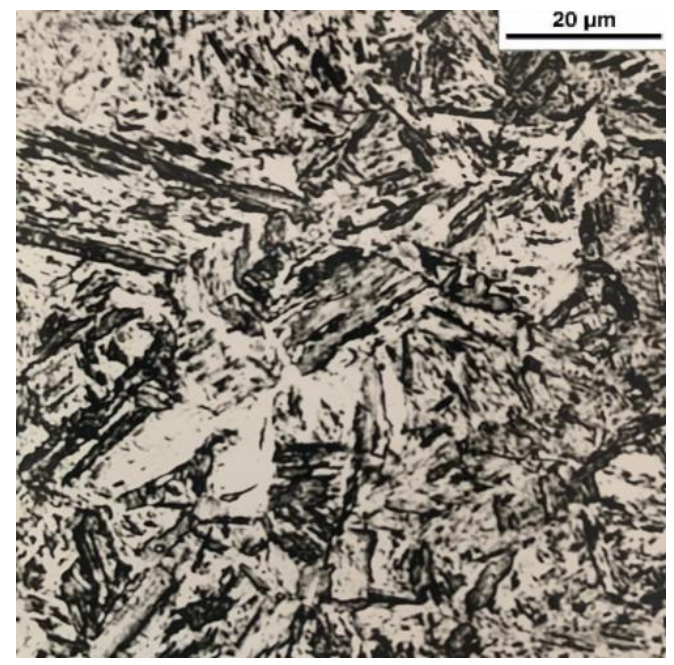

Fig. 8. Welding microstructure in DOCOL $1200 \mathrm{M}$ welded MAG steel with $98 \% \mathrm{Ar}+2 \% \mathrm{O}_{2}$

Figures 7 and 8 show martensite, ferrite and traces of bainite. After welding the steel in a $98 \% \mathrm{Ar}+2 \% \mathrm{O}_{2}$ shielding gas mixture, ferrite was observed. The more favorable structure is after welding of DOCOL $1200 \mathrm{M}$ steel with a MAG process in $82 \% \mathrm{Ar}+18 \% \mathrm{CO}_{2}$.

\section{Summary}

The increase of operational parameters (load capacity, range) while maintaining the mass of mobile platforms of motor vehicles can be obtained by modifying the technology of welding AHSS steel structures. However, this technology requires further development and additional research. The article shows that in the welding process of AHSS steels the correct choice of the gas mixture plays an important role. Nondestructive examinations were carried out, as well as examinations of the structure and tensile strength. Three different shield gases were tested. The best results were obtained by welding elements of a mobile platform made of AHSS steel using the MAG process in the $82 \% \mathrm{Ar}+18 \% \mathrm{CO}_{2}$ shielding gas mixture. The destructive and non-destructive tests of joints confirm that elements of mobile platforms made of AHSS steel can be welded together with satisfactory quality. 
Conflicts of Interest: The authors declare no conflict of interest.

\section{References}

[1] Waldemar P., Maintenance of mobile elevating work platforms. ISBN 978-83-62760-07-7, Publisher Kabe, Krosno, 2015.

[2] Skowrońska B., Szulc J., Chmielewski T., Golański D., Selected properties of Plasma+MAG welded joints of S700 MC steel. Welding Technology Review, 2017, Vol. 89(9), 104-111. [CrossRef]

[3] Skowrońska B., Szulc J., Chmielewski T., Sałaciński T., Swiercz R., Properties and microstructure of hybrid Plasma+MAG welded joints of thermomechanically treated S700MC steel. Proceedings of the 27th Anniversary International Conference on Metallurgy and Materials (METAL), Brno, Czech Republic, 25 May 2018.

[4] Jason L., Kamran A., Jwo P., Modeling of failure mode of laser welds in lap-shear speciments of HSLA steel sheets. Engineering Fracture Mechanics, 2011, No. 1, 347-396.

[5] Celin R., Burja J., Effect of cooling rates on the weld heat affected zone coarse grain microstructure. Metallurgical and Materials Engineering, 2018, Vol. 24(1). [CrossRef]

[6] Darabi J., Ekula K., Development of a chip-integrated micro cooling device. Microelectronics Journal 2003, Vol. 34(11), 1067-1074. [CrossRef]

[7] Górka J., Ozgowicz A., Matusek K., Robotic spot welding of Docol 1200M steel. Welding Technology Review, 2019, vol. 91(4), 33-38. [CrossRef]

[8] Hadryś D., Impact load of welds after micro-jet cooling. Archives of Metallurgy and Materials, 2015, Vol. 60(4), 2525-2528. [CrossRef]

[9] Jaeschke B., Węglowski M., Chmielewski T., Current State and Development Opportunities of Dynamic Power Source for GMA Welding Processes. Journal of Manufacturing Technologies, 2017, Vol. 42(1), 23-30.

[10] Wojnarowski K., Skowrońska B., Chmielewski T., Golański D., Comparison of welding condition of different thickness joints of ø1016 L485ME steel welded with 135/136 methods. Welding Technology Review, 2018, Vol. 90(5), 155-159. [CrossRef]

[11] Muszynski T., Mikielewicz D., Structural optimization of microjet array cooling system. Applied Thermal Engineering 2017, Vol. 123, 103-110. [CrossRef]

[12] Walsh S.M., Smith J.P., Browne E.A., Hennighausen T.W., Malouin B.A., Practical Concerns for Adoption of Microjet Cooling. ASME Proceedings 2018 Power Electronics, Energy Conversion, and Storage. [CrossRef]

[13] https://www.yumpu.com/docol-m-zimnowalcowana-stal-martenzytyczna-ssab

[14] https://www.thyssenkrupp-steel.com/media/content_1/publikationen/grobblech_migration/perform/ verarbeitung_1/schweissen_1/klassifikation_der_schweisszusaetze.pdf

[15] Kah P., Pirinen M., Suoranta R., Martikainen J., Welding of ultra high strength steels. Advanced Materials Research, 2014, Vol. 849, 357-365. [CrossRef]

[16] Sharma R.S., Molian P., Weldability of advanced high strength steels using an Yb:YAG disk laser. Journal of Materials Processing Technology, 2011, Vol. 211(11), 1888-1897. [CrossRef]

[17] Li J., Nayak S.S., Biro E., Panda S.K., Goodwin F., Zhou Y., Effects of weld line position and geometry on the formability of laser welded high strength low alloy and dual-phase steel blanks. Materials E Design (1980-2015), 2013, Vol. 52, 757-766. [CrossRef]

[18] Górka J., Ozgowicz A., Robotic welding of high-strength DOCOL 1200M steel with laser seam stepper system, Welding Technology Review, 2017, Vol. 89(10), 15-20. [CrossRef]

[19] Godwin K., Yong O., Microstructure and fatigue performance of buttwelded joints in advanced high-strength steels, Materials Science \& Engineering, 2014, A 597, 342-348. [CrossRef]

[20] Górka J., Weldability of thermomechanically treated steels having a high yield point, Archives of Metallurgy and Materials, 2015, Vol. 60(1), 469-475. [CrossRef]

(C) 2019 by the authors. Submitted for possible open access publication under the terms and conditions of the Creative Commons Attribution (CC BY) license (http://creativecommons.org/licenses/by/4.0/). 